\title{
A Study into the Relationships among Consumers' Diet-Focused Behaviors, Organic Nutrition, and Environmentally Conscious Behaviors
}

\author{
Tüketicilerin Diyete Yatkınlıkları, Organik Beslenme ve Çevreye Duyarlı \\ Davranışları Arasındaki İlişki Üzerine Bir Araştırma \\ Güzide Öncü EROĞLU PEKTAŞ* \\ Merve YANAR GÜRCE ${ }^{* *}$
}

\begin{abstract}
Currently, consumers can be game-changing supporters of a more sustainable world by being healthy and environmentally conscious and opting for food produced in view of social responsibility. It is evident that there are relationships among healthy food, life style, and environmentally conscious consumption and consumers have been becoming more concerned about their own health and environmental issues. The present study conducted to this end revealed relationships among diet-focused behaviors, organic nutrition, and environmentally conscious behaviors. The data was collected with online questionnaires and a statistical software program, was used to conduct the regression analyses, frequency analyses and factor analyses of the data. Results show that there is a significant relationship between consumers 'diet-focused behaviors, organic nutrition and environmentally conscious behaviors.
\end{abstract}

Key Words: Diet-focusedness, organic nutrition, environmental conscious behavior, sustainable consumption

$\ddot{\mathbf{O} z}$

Günümüzde tüketiciler hem sağlıklı hem de çevreye duyarlı olarak ve sosyal sorumluluk anlayışı ile üretilen besinleri seçerek daha sürdürülebilir dünyanın önemli birer destekçileri olabilmektedirler. Sağlıklı besinler, yaşam stilleri ve çevreye duyarlı tüketim arasında bir ilişkinin bulunduğu görülmektedir ve tüketiciler de günden güne kendi sağlıkları ve çevreyle ilgili konular için daha fazla endişe duymaya başlamışlardır. Bu doğrultuda gerçekleştirilen çalışma ileçevreye duyarlı davranış, sağlık bilincine sahip yaşam tarzı, beslenme ve etik tüketim arasındaki ilişkide algılanan tüketici etkinliğinin düzenleyici rolü araştırılmıştır. Çalışmanın verileri katılımcılardan online anket yoluyla elde edilmiştir ve değişkenler arasındaki ilişkileri ölçmek için sosyal bilimlerde sıklıkla kullanılan bir programda analizleri yapılmıştır. Örneklemin veri analizinde regresyon analizi, frekans analizi, faktör analizleri kullanılmıştır. araştırmadan elde edilen bulgulara göre, tüketicilerin diyete yatkınlıkları, organik beslenme alışkanlıkları ve çevreye duyarlı davranışları arasında anlamlı bir ilişki olduğu görülmektedir.

Anahtar Kelimeler: Algılanan tüketici etkinliği, çevreye duyarli davraniş, sürdürülebilir tüketim

\section{Introduction}

Currently, an increased number of obesity cases and other health issues have turned into serious global problems (Kleef \& Dagevos, 2015, p. 292). One of the reasons is the consumption of such nutrients as sugar, sodium and saturated fat acids more than recommended (Macdiarmid et al., 2012, p. 634). Food systems are considered to be among the factors causing greenhouse gases due to the processes including growing, processing, packaging, distribution, consumption and removal (Macdiarmid et al., 2012, p. 635).Increasing purchasing power in the modern world, competitive market structures and different cultural structures and societies have become more individual-and consumption-focused. Modernization's dominance over the nature and environment has boosted individualistic approaches along with the strengthening consumption culture, which has resulted in underdeveloped environmental consciousness. Therefore, consumers can contribute to the efforts to create a more sustainable world by adopting a sustainable consumption understanding and opting for food which is healthy and produced by observing the ethical standards based on environmental consciousness (Zander \& Hamm, 2010, p. 498). The primary concern of the present study conducted to this end is to

\footnotetext{
Dr.Öğr.Üyesi, İstanbul Üniversitesi Mühendislik Fakültesi, Deniz Ulaştırma İşletme Mühendisliği, guzideoncum@hotmail.com

*** Dr.Öğr.Üyesi, İstanbul Gedik Üniversitesi, İktisadi, İdari ve Sosyal Bilimler Fakültesi, Uluslararası Ticaret ve Finans Bölümü, merveynr@yahoo.com
}

Eroğlu Pektaş, G. Ö., Yanar Gürce, M., (2018). A Study into the Relationships among Consumers’ Diet-Focused Behaviors, Organic Nutrition, and Environmentally Conscious Behaviors, Gaziantep University Journal of Social Sciences, 17 (4), 1507-1515, Submission Date: 08-06-2018, Acceptance Date: 27-09-2018.

Araştırma Makalesi. 
reveal the relationships among diet-focused, organic nutrition, and environmentally conscious behaviors.

In today's world, there is a new consumer profile that is renewed continuously, and improves thyself with healthy living rules. Through smartphones and new phone applications, they provide both a more convenient flow of information and a model for reference groups in their near surroundings. All of this contribute to the environmental consciousness behavior and creates interaction between environmentally conscious consumers.

With the increasing rates of obesity, heart and allergic diseases, awareness about healthy life and sustainable consumption issues are increasing all over the world. Through this study, it is thought to be important in terms of determining the consumer behaviors in the market of organic foods, sports products, healthy life and diet products, which are studied rarely in literature. According to that, the aim of this study is to find out whether there is a relationship between consumers' diet-focused behaviours, organic nutrition and environmentally conscious behaviors.

\section{Material and Method}

\section{Environmentally Conscious Behavior}

Perceived consumer effectiveness as a decisive factor for individuals to adopt an environmentally conscious behavior can be used to explain such concepts as environmentally conscious behavior and attitudes. The concept is mostly associated with social awareness and environmentally conscious behavior and is referred to as consumers' beliefs that they can contribute to the solution to a social and environmental problem by making a difference (Ellen et al., 1991, p. 105).

Perceived consumer effectiveness as a concept was first discussed by Kinnear, Taylor and Ahmed (1974) to assess individuals' beliefs as to whether they can make a difference with their individual efforts. Accordingly, an individual's intention and behavior are indicative of the belief that the occurrence or discontinuation of a behavior depends on individual's actions (Thompson, 1981, p. 307).

In a study, it is defined as individuals' self-evaluations concerning a certain problem (Berger \& Corbin, 1992, p. 80) and differs from attitudes by its ability to evaluate a problem (Tesser \& Shaffer, 1990, s.481). Some studies in the related literature report that consumers' attitudes and environmentally conscious reactions potentially make positive differences thanks to the outcomes of this concern (Aaker \& Bagozzi, 1982, p. 93; Roberts \& Bacon, 1997, p. 230).

If consumers believe that their behaviors will have an effect on outcomes they desire, perceived consumer effectiveness can affect their behaviors. Therefore, a high level of perceived consumer effectiveness is necessary for consumers to translate their positive attitudes into purchasing behaviors (Vermeir \& Verbeke, 2006, p. 172). As stated in the literature, the fundamental role of perceived consumer effectiveness is to motivate consumers to buy environmentally and socially conscious items called sustainable products (Jacobs et al, 2015, p. 9; Vermeir \& Verbeke, 2006, p. 172). Thus, with environmental and social sensitivity individuals are evoked to develop consciousness. Businesses should not only produce and sell goods and services but also be able to develop and promote perceived consumer effectiveness.

According to a study, consumers should be convinced to be able to bring about behavioral changes that their behaviors exert decisive effects on such issues as environmental disruption or social inequality (Roberts, 1996, p. 43). This should invoke an understanding of social responsibility in businesses and they should convince their target mass to act accordingly. 
If the level of perceived consumer effectiveness is increased, then consumers can be motivated to be more environmentally conscious and to purchase more sustainable products (Gellynck \& Verbeke, 2013, p. 14). There are some studies into the effects of perceived consumer effectiveness on the purchase of sustainable products (Jacobs et al, 2015, p. 9; Vermeir \& Verbeke, 2006, p. 54), but there is a substantial need for research into the choice of sustainable food (Avermaete \& Mathijs, 2008, p. 33). According to that this study is intended to satisfy the need to some extent.

\section{Sustainable Consumption}

Each modern community creates its own structure characterized by a competitive market, complex cultural structure and consumption-based economy. The communities different from each other recklessly and fiercely exploit global resources. Modernization's dominance over the nature and environment has boosted individualistic approaches along with the strengthening consumption culture, which has resulted in underdeveloped environmental consciousness.

Broadly speaking, consumption is a dynamic process where social categories, culture and boundaries are incessantly redefined. Merchandises, except for nutrition, drinking, and shelter, are a kind of device of thinking, and also a non-verbal communication form of humans' ability to create (Zorlu, 2006, p. 236). Today, consumption studies have gone beyond psychology- and sociology-based marketing research and come to include environmental consciousness. The main reason for such a paradigmal shift is the fact that the burden caused by environmental effects associated with consumption (and production as the offering side) on nature has exceeded a certain threshold. In the literature, a greater focus is placed on per-capita consumption in developed countries, how much we have exceeded Earth' bearing capacity and the fact that consumption is not sustainable anymore (Özsoy, 2011, p. 71).

United Nations Commission on Sustainable Development (CSD) characterizes "Sustainable Consumption" in consideration of quality of life and intergenerational equality. Both concepts focus on not only the process but also goods and services. In other words, a comprehensive emphasis is put on all the processes in a life cycle (UNEP, 2004). Sustainable Consumption is defined in the 2002 report of the OECD as "the use of services and related products which respond to basic needs and bring a better quality of life while minimizing the use of natural resources and toxic materials as well as the emissions of waste and pollutants over the life-cycle of the service or product so as not to jeopardize the needs of future generations". Although this definition can be interpreted in different ways, there is a consensus on the fact that the use of resources by developed countries should be reduced. Meulenberg (2003) refers to sustainable consumption as the social responsibility of consumers and a decision-making process considering individuals' needs and demands.

Marchand, Walker, and DeConinck (2004) describe sustainable consumption with the following terms and statements (Özsoy, 2011, p. 74):

Abstention: Abstaining from consumption or, sometimes, consuming less,

Attitude: Considering consumption of more than needed as a negative act,

Awareness: Choosing products in view of their ecological qualities,

Alternative: Identifying consumption styles alternative to traditional consumption.

In the new world order, which came into being with neo-liberal policies after the World War II, a growing interest in the concept of consumption is observable in both daily life and social sciences. The drive underlying the new world order is "consumption of the produced". At the present time, when individuals' clothing styles and products they consume are regarded 
as a communication vehicle and an indicator of social status, the main purpose of consumption is to be revered at higher exchange rates (Doğan et al., 2015, p. 662).

\section{Research}

The primary concern of the present study is to reveal whether there are relationships among diet-focused, organic nutrition, and environmentally conscious behaviors. Although there are studies evidencing the relationship between environmentally conscious behaviors and sustainable purchasing behavior (Jacobs et al, 2015; Vermeir \& Verbeke, 2006, p. 44), no research in the literature was identified to tackle how they affect consumers' behaviors concerning health, nutrition, and ethical consumption. Apart from this exiguousness, practiceoriented studies too are very scanty. Hence, the present research study is anticipated to serve as a vital source of motivation to respond to the need for further research on this issue thanks to its attempt to reveal the relationship between such nutrition preferences as diet-focused and organic nutrition and environmentally conscious behavior.

The sample of the research consists of consumers at the age of 18 and over. A questionnaire was administered as the data collection tool. The questionnaire forms were delivered to the participants via such social media as Facebook and Instagram and e-mails; as a result, 220 questionnaires were returned and analyzed. To produce the questionnaire, the researchers exploited Whitmarsh (2009) to assess environmentally conscious behavior, Gil, Gracia \& Sanchez (2000) to assess diet-focused behavior, and Steptoe, Pollard \& Wardle (1995) to assess understanding of organic nutrition. 6 demographic questions were included in the questionnaire to collect data on the participants' genders, ages, incomes, marital status, educational background, and professions. The questionnaire contains 4 items to assess environmentally conscious behavior, 3 to assess diet-focused behavior, and 7 to assess organic nutrition behavior. Thus, the questionnaire consists of 20 items. It is a 5-level likert scale. The levels are " $1=$ strongly disagree", " $2=$ disagree", " $3=$ neither agree nor disagree", "4=agree", and " $5=$ strongly agree".

The sample consists of 220 participants due to temporal and cost-related limitations. Future research may focus on a different and larger sample, which is believed to make greater contribution to the literature.

\section{Research Model and Hypotheses}

Because the purpose of the present research is to reveal the relationships among dietfocused behaviors, organic nutrition behaviors, and environmentally conscious behaviors, the hypotheses below were constructed in consideration of the available literature: The independent variables of the study are diet-focused behavior and organic nutrition, while environmentally conscious behavior refers to the dependent variable. Accordingly, the model and hypotheses of the research are as follows: 


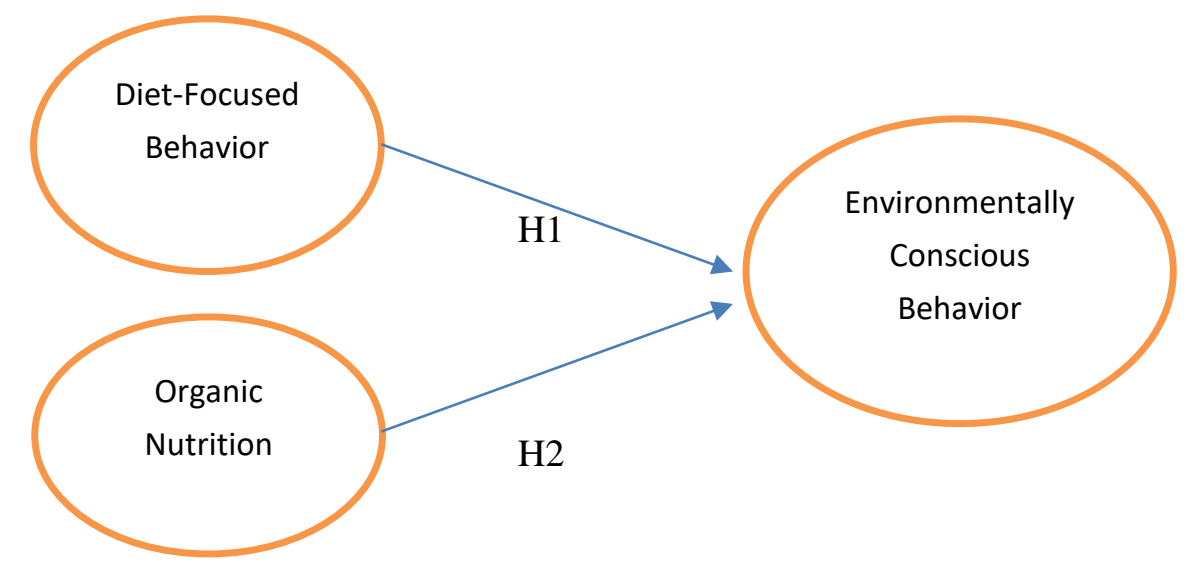

Fig. 1 Research model

H1: There is a positive relationship between diet-focused behavior and environmentally conscious behavior

$\mathrm{H} 2$ : There is a positive relationship between organic nutrition and environmentally conscious behavior

\section{Findings}

Table 1 show that $54.5 \%$ and $45.5 \%$ of the participants are female and male, respectively. $37.7 \%$ are married and $62.3 \%$ are single. Moreover, $4 \%$ are $18,46.8 \%$ are $18-29$, $23.6 \%$ are $30-39,9.5 \%$ are $40-49$, and $14.0 \%$ are $50-59$ years old. $1.3 \%, 27.7 \%, 9 \%, 59 \%$, and $2.7 \%$ hold elementary and middle school, high school, associate's, bachelor's and postgraduate degrees, respectively. The incomes of the participants amount to 1001-2000 TL for $12.2 \%$, 2001-3000 TL for 13.6\%, 3001-4000 TL for 32.2\%, 4001-5000 TL for 12.2\% and 5000 TL and above for $25.0 \%$.

\section{Analysis}

Table 1: Demographic characteristics of the participants

\begin{tabular}{|c|c|c|c|}
\hline \multicolumn{2}{|c|}{ Demographic Characteristics } & Frequency & Percentage \\
\hline \multirow{3}{*}{ Gender } & Female & 120 & 54.5 \\
\hline & Male & 80 & 45.5 \\
\hline & Total & 220 & 100 \\
\hline \multirow{3}{*}{ Marital Status } & Married & 83 & 37.7 \\
\hline & Single & 137 & 62.3 \\
\hline & Total & 220 & 100 \\
\hline \multirow{6}{*}{ Age } & Under 18 & 3 & 4 \\
\hline & $18-29$ & 103 & 46.8 \\
\hline & $30-39$ & 52 & 23.6 \\
\hline & $40-49$ & 21 & 9.5 \\
\hline & $50-59$ & 31 & 14 \\
\hline & Total & 220 & 100 \\
\hline \multirow{6}{*}{$\begin{array}{l}\text { Educational } \\
\text { Background }\end{array}$} & $\begin{array}{l}\text { Elementary and Middle } \\
\text { School }\end{array}$ & 3 & 1.36 \\
\hline & High school & 61 & 27.7 \\
\hline & Vocational School & 20 & 9 \\
\hline & University & 130 & 59 \\
\hline & Postgraduate & 6 & 2.7 \\
\hline & Total & 220 & 100 \\
\hline \multirow{3}{*}{ Income } & $1001-2000 \mathrm{TL}$ & 27 & 12.2 \\
\hline & $2001-3000 \mathrm{TL}$ & 30 & 13.6 \\
\hline & $3001-4000 \mathrm{TL}$ & 71 & 32.2 \\
\hline
\end{tabular}




\begin{tabular}{|c|l|c|c|}
\hline \multirow{4}{*}{} & $4001-5000 \mathrm{TL}$ & 27 & 12.2 \\
\cline { 2 - 4 } & 5000 and over & 55 & 25 \\
\cline { 2 - 4 } & Total & $\mathbf{2 2 0}$ & $\mathbf{1 0 0}$ \\
\hline
\end{tabular}

Whether the data from the sample were suitable for exploratory factor analysis can be tested with Kaiser-Meyer-Olkin (KMO) test and Bartlett's Test (Çokluk \& Şekercioğlu \& Büyüköztürk, 2012, p. 207). The high Kaiser-Meyer-Olkin value means that each variable in the scale can be perfectly predicted by the other variables. When values amount to or are close to 0 (zero), no interpretation can be performed based on these values because a scattered pattern occurs in the correlation distribution. In the event that the value is calculated to be under 0.50 with the Kaiser-Meyer-Olkin measure, then the analysis cannot be continued with a factor analysis (Çokluk et al., 2012, p. 207).

Table 2: KMO and Bartlett's test results

\begin{tabular}{|l|l|r|}
\hline \multicolumn{2}{|c|}{ KMO and Bartlett's Test } \\
\hline Kaiser-Meyer-Olkin (KMO) Test for Sampling Adequacy & .879 \\
\hline \multirow{2}{*}{ Bartlett's Test } & Chi-Square & 1849.117 \\
\cline { 2 - 3 } & Sd & 105 \\
\cline { 2 - 3 } & Sig. & .000 \\
\hline
\end{tabular}

The results from the Bartlett's Test and Kaiser-Meyer-Olkin test are provided in Table 2. As indicated in Table 2, the KMO value is 0.87 , which signifies that the sampling size is suitable to conduct a factor analysis (Çokluk et al., 2012: 207). Besides, the Bartlett's Test of Sphericity shows that Chi-Square value is significant $(\mathrm{X} 2(105)=1849,117 ; \mathrm{p}<.01)$.

Table 3: The scale's factor loadings and Cronbach's alpha coefficients

\begin{tabular}{|c|c|c|c|}
\hline Variable & Items & $\begin{array}{l}\text { Factor } \\
\text { Loading }\end{array}$ & $\begin{array}{l}\text { Cronbach's } \\
\text { Alpha }\end{array}$ \\
\hline \multirow{7}{*}{  } & It is important for me that it should not contain additives. & 0.736 & \multirow{7}{*}{0.908} \\
\hline & It is important that it should only contain natural nutrients. & 0.557 & \\
\hline & It should be vitamin- and mineral-rich. & 0.810 & \\
\hline & It is important that it should be nutritious. & 0.769 & \\
\hline & It is important that it should be protein-rich. & 0.805 & \\
\hline & It is important that it should be good for my health. & 0.846 & \\
\hline & Fiber-rich foods & 0.652 & \\
\hline \multirow{4}{*}{ 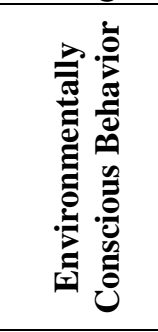 } & $\begin{array}{l}\text { I may not choose to purchase products with no social } \\
\text { responsibility. }\end{array}$ & 0.705 & \multirow{4}{*}{0.787} \\
\hline & I change the products with no social responsibility. & 0.715 & \\
\hline & $\begin{array}{l}\text { It is important for me to see the information on the tag that } \\
\text { the product has been produced with minimal environmental } \\
\text { hazard. }\end{array}$ & 0.795 & \\
\hline & $\begin{array}{l}\text { It is important for me that the product I purchase has been } \\
\text { packaged with minimal environmental hazard. }\end{array}$ & 0.765 & \\
\hline \multirow{3}{*}{ 党 } & It should be a low-calorie product. & 0.846 & \multirow{3}{*}{0.832} \\
\hline & $\begin{array}{l}\text { It is important that the product should help me with weight } \\
\text { control. }\end{array}$ & 0.740 & \\
\hline & It is important that it should contain a low amount of fat. & 0.759 & \\
\hline
\end{tabular}

Regression analyses were conducted to test whether there were significant relationships among diet-focused behavior, organic nutrition, and environmentally conscious behavior. The results are presented in Table 3.

Table 4: Regression analysis

\begin{tabular}{|l|r|r|l|c|}
\hline \multicolumn{7}{|c|}{ Model Summary } \\
\hline Model & $\mathrm{R}$ & R Square & $\begin{array}{l}\text { Adjusted R } \\
\text { Square }\end{array}$ & $\begin{array}{c}\text { Std. Error of the } \\
\text { Estimate }\end{array}$ \\
\hline & $.489 \mathrm{a}$ & .239 & .232 & .66921 \\
\hline
\end{tabular}


H1: There is a positive relationship between diet-focused behavior and environmentally conscious behavior.

Ho is rejected because $\mathrm{F}$ value (sig.) of correlation coefficient concerning the relationship between the independent variable diet-focused and the dependent variable environmentally conscious behavior is 0.000 . Thus, $\mathrm{H} 1$ is accepted and there is a positive relationship between diet-focused and environmentally conscious behavior.

H2: There is a positive relationship between organic nutrition and environmentally conscious behavior.

Ho is rejected because $\mathrm{F}$ value (sig.) of correlation coefficient concerning the relationship between the independent variable organic nutrition and the dependent variable environmentally conscious behavior is 0.000 . Thus, $\mathrm{H} 2$ is accepted and there is a positive relationship between organic nutrition and environmentally conscious behavior.

These findings indicate the significance of the research model. An R Square value of .240 refers to the exploratory value of the analysis. Hence, the model has an explanatoriness of $24 \%$.

\section{Conclusion and Suggestions}

In the new postmodern marketing world, where globalization has rapidly increased, technology has become highly advanced, and consumption is faster than ever, all the marketing rules have changed fast over the last two years and is likely to change and develop in various ways in five years' time. Coupled with the sophisticated modern life and complex human structure, the rapid change and transformation have led humans to exploit and destroy Earth maliciously.

As stated in the literature, the fundamental role of perceived consumer effectiveness is to motivate consumers to buy environmentally and socially conscious items called sustainable products (Jacobs et al, 2015:9; Vermeir \& Verbeke, 2006, p. 172). Thusly, with environmental and social consciousness, individuals are evoked to develop consciousness. Businesses should not only produce and sell goods and services but also be able to develop and promote perceived consumer effectiveness.

The primary concern of the present study is to reveal whether there are significant relationships among diet-focused behaviors, organic nutrition habits, and environmentally conscious behaviors. To this end, a questionnaire was administered to consumers at the age of 18 and over. The obtained data were evaluated with frequency analyses, factor analyses, and regression analyses.

The results demonstrate that $54.5 \%$ and $45.5 \%$ of the participants are female and male, respectively. Married and single participants account for $37.7 \%$ and $62.3 \%$ of the sample, respectively. Moreover, $4 \%$ are under $18,46.8 \%$ are $18-29,23.6 \%$ are $30-39,9.5 \%$ are $40-49$, and $14.0 \%$ are $50-59$ years old $1.3 \%, 27.7 \%, 9 \%, 59 \%$, and $2.7 \%$ hold elementary and middle school, high school, associate's, bachelor's and postgraduate degrees, respectively. The incomes of the participants amount to 1001-2000 TL for 12.2\%, 2001-3000 TL for $13.6 \%$, $3001-4000$ TL for $32.2 \%$, 4001-5000 TL for $12.2 \%$ and $5000 \mathrm{TL}$ and above for $25.0 \%$.

The results of the regression analyses performed to demonstrate whether there were significant relationships among diet-focused behaviors, organic nutrition habits and environmentally conscious behaviors show that there is a significant relationship between dietfocused behavior and environmentally conscious behavior and also between organic nutrition and environmentally conscious behavior. This refers to the significance of the adopted model. 
Generally, the obtained results evidence that individuals exhibiting organic nutrition habits and diet-focused behaviors are more conscious of environmental issues. As indicated by these results, individuals more willing to contribute to socially and environmentally a more sustainable world were also found to care about their health, to adopt a lifestyle with a higher level of diet-focused attitude and to eat healthier food. Thus, these results are expected to make notable contributes to marketing practices. The emphasis on the fact that food introduced to markets are more organic and suitable for diet is likely to result in environmentally and socially more conscious purchases, which will in return contribute to the efforts to create a more sustainable world. The results show a number of points of interest for policy-makers and marketing practioners that want to promote healthy food products for a more sustainable World

This research study's original subject, which have not been sufficiently investigated before, and its attempt to develop an original model evidence its originality. However, a larger sampling in future studies is thought to contribute greatly to the related literature and the study can be extended to another countries or regions.

\section{References}

Aaker, D. A., \& Bagozzi, R. P. (1982). Attitudes toward public policy alternatives to reduce air pollution. Journal of Marketing, 1, 85-94.

Aracıoğlu, B., \& Tatlıdil, R. (2009). Tüketicilerin satın alma davranışında çevre bilincinin etkileri; Ege Akademik Bakış, 9(2), 435-461.

Avermaete, T., \& Mathijs, E. (2008, 26-29 August). Sustainable food versus health concerns. Proceedings of the International Congress of European Association of Agricultural Economists, Ghent: Belgium.

Ay, C., \& Ecevit, Z. (2005). Çevre bilinçli tüketiciler. Akdeniz İ.I.B.F. Dergisi, 10, 238-263.

Berger, I.E., \& Corbin, R.M. (1992). Perceived consumer effectiveness and faith in others as moderators of environmentally responsible behaviours. Journal of Public Policy and Marketing, 11, 79-89.

Bimbo, F.; Bonanno, A., Nocella, G., Viscecchia, R., Nardone, G., Biagia De D., \& Carlucci, D. (2017). Consumers' acceptance and preferences for nutrition-modified and functional dairy products: A Systematic Review, Elsever.

Çokluk, Ö.; Şekercioğlu, G., \& Büyüköztürk, Ş. (2012). Sosyal bilimler için çok değişkenli istatistik spss ve lisrel uygulamalart. Pegem akademi: Ankara.

Doğan, O.; Bulut, Z. A., \& Çımrın, F. K. (2015). Bireylerin sürdürülebilir tüketim davranışlarının ölçülmesine yönelik bir ölçek geliştirme çalışması. Íktisadi ve İdari Bilimler Dergisi, 29(4).

Ellen, P.S., Wiener, J.L., \& Cobb-Walgren, C. (1991). The role of perceived consumer effectiveness in motivating environmentally conscious behaviors. Journal of Public Policy \& Marketing, 102-117.

Jacobs, S., Sioen, I., De Henauw, S., Rosseel, Y., Calis, T., Tediosi, A., Nadal, M., Marques, A. \& Verbeke, W. (2015). Marine environmental contamination: Public awareness, concern and perceived effectiveness in five european countries. Environmental Research, 143, 4-10.

Karaboğa, Tahir. (2016). Çevre sosyolojisinde çevre sorunlarına yönelik alternatif arayışlar. Uluslararası Hakemli Sosyal Bilimler E-Dergi, Mayıs-Haziran, 716.

Kleef, E.V., \& Dagevos, H. (2015). The growing role of front-of-pack nutrition profile labeling: a consumer perspective on key issues and controversy. Critical Reviews in Food Science and Nutrition, 5(3), 291-303.

Liran C. S., Aoife De B., Maeve H., Chenguang L., Celine M., Patrick G. W., Frank J. M. (2017). Consumer evaluations of processed meat products reformulated to be healthier a conjoint analysis study. Meat Scince, 82-89. 
Lucía A., Ana G., Florencia A., Leticia V., Gastón A. (2017). Consumer perception of saltreduced breads: comparison of single and two bites evaluation, Food Research Internationa.

Macdiarmid, J.I., Kyle, J., Horgan, G.W., Loe, J., Fyfe, C., Johnstone, A. \& McNeill, G. (2012). Sustainable diets for the future: can we contribute to reducing greenhouse gas emissions by eating a healthy diet? The American Journal of Clinical Nutrition, 96(3), 632-639.

Ma1, R., \& Hoffmann, S. (2012). Taste lovers versus nutrition fact seekers: How health consciousness and self-efficacy determine the way consumers choose food products; Journal of Consumer Behavior, J. Consumer Behave, 11, 316-328.

Roberts, J. A. (1996). Green consumers in the 1990s: profile and implications for advertising Journal of Business Research, 36(3), 217-231.

Roberts, J. A., \& Bacon, D. R. (1997). Exploring the subtle relationships between environmental concern and ecologically conscious consumer behavior. Journal of Business Research, 40(1), 79-89.

Tanrıkulu, C. (2015). Çevresel kaygı, algılanan tüketici etkinliği ve kolektivizm tüketicilerine yeşil satın alma davranışlarındaki rolü üzerine bir inceleme. Atatürk Üniversitesi İktisadi ve İdari Bilimler Dergisi, 29(1).

Tesser, A., \& David R. S. (1990). Attitudes and attitude change. Annual Review of Psychology, 41, 479-523.

Thompson, S. C. (1981). Will it hurt less if i can control it? A Complex answer to a simple question in advances in consumer research. Andrew Mitchell, ed., Vol. 9306-312.

Vanhonacker, F., Van L., Gellynck, X., \& Verbeke, W. (2013). Flemish consumer attitudes towards more sustainable food choices. Appetite, 62, 7-16.

Vermeir, I., \& Verbeke, W. (2006). Sustainable food consumption: Exploring the consumer attitude-behavioral intention gap. Journal of agricultural and environmental ethics, 19(2), 169-194.

Yıldız, S. B., \& Kılıç, S. N. (2016). Lisans düzeyinde turizm eğitimi alan öğrencilerin çevre dostu ürünlere ilişkin tutum ve davranışları. International Journal of Human Sciences, 13(1), 1304-1323.

Zander, K., \& Hamm, U. (2010). Consumer preferences for additional ethical attributes of organic food. Food Quality and Preference, 21(5), 495-503.

Tijssen, I., Zandstra, E. H., Cees D. G., \& Jager, G. (2017). Why a 'light' product package should not be light blue: effects of package color on perceived healthiness and attractiveness of sugar- and fat-reduced products, Food Quality and Preference, 59, 4658. 